\title{
PARAMOUNT CLAUSE IN THE INTERNATIONAL TRANSPORT OF GOODS BY ROAD AND RAIL
}

DATA PRZESŁANIA: 25.07.2018, DATA AKCEPTACJI: 18.08.2018, JEL CODES: K12, K22

\section{Konrad Garnowski}

Wydział Zarządzania i Ekonomiki Usług, Uniwersytet Szczeciński konrad.garnowski@wzieu.pl

The paramount clause is the particular in the consignment note drawn during the performance of international carriage of goods by road and rail, according to which the carriage is subject to the provisions of applicable convention, notwithstanding any clause to the contrary. Inclusion of the entry is one of the carrier's obligations, which in practice is not always performed. In the article the author describes the consequences of the lack of such particular and indicates situations in which the carrier may be held liable for the damage caused by this omission. However, the author eventually presents the view that due to the serious evidential difficulties it would be unlikely to obtain damages for the failure to include the paramount clause.

\section{INTRODUCTION}

Provisions of international transport law regarding road and rail transport introduce the concept of the paramount clause. This clause is a statements included in the consignment note that the carriage is subject, notwithstanding any clause to the contrary, to the provisions of applicable convention. The requirement to include such particular in the consignment note can be found in Article $6(2)(\mathrm{k})$ of the CMR convention ${ }^{1}$ and Article $6 \$ 1(\mathrm{p})$ of the CIM convention. ${ }^{2}$ None of the acts expressly indicates that this clause is supposed to be included by the carrier, but there should be no doubt in this regard, since both of them stipulate that the carrier is the person liable

1 Convention on the Contract for the International Carriage of Goods by Road signed in Geneva on 19 may 1956.

2 Uniform Rules Concerning the Contract of International Carriage of Goods by Rail (CIM) - Appendix B to the Convention concerning International Carriage by Rail (COTIF) of 9 May 1980 as amended by the Protocol of Modification of 3 June 1999 (Vilnius). 
for the lack of it (Article 7 (1) (3) CMR, Article $8 \$ 3$ CIM). It should be also noted, by way of a preliminary remark, that the Montreal Convention ${ }^{3}$ does not provide for a similar regulation, but the Warsaw Convention, ${ }^{4}$ as amended by the Hague Protocol, ${ }^{5}$ imposed an obligation to include in the consignment note the information which was only to some extent similar to the paramount clause (Article 8(c)). However, this particular was only intended to have informative character and was merely a warning that the contract of carriage may be governed by Warsaw Convention, which "generally limits the liability of the carrier in the event of loss or damage of the goods" (see also Clarke, Yates, 2008, p. 343).

In many situations presence or lack of the paramount clause during the performance of the transport of goods by road or by rail has no practical relevance. Nevertheless, there are some situations, when it can affect the legal relationship between the parties by indicating the legal regime applicable to the contract of carriage. There are also certain problems which may arise due to the lack of this clause in case of any damage to the cargo during performance of the carriage. Even so, there are not many judicial decisions regarding the application of this clause and the doctrine has also only briefly mentioned the issues connected with it (Dąbrowski in: Ambrożuk, Dąbrowski, Wesołowski, 2015, p. 115; Clarke, 2009, p. 60; Godlewski, 2007, p. 42; Hill, Messent, Glass, 2000, p. 72; Mercadal in: Theunis, 1987, p. 34). The purpose of this paper is to analyse the potential results of the lack of paramount clause in the consignment note and to establish the scope of the carrier's liability.

\section{CHARACTER OF THE PARAMOUNT CLAUSE}

When discussing the importance of the paramount clause, the reference should be made to the regulations determining the scope of application of the conventions in question. Pursuant to Article 1 (1) CMR, the convention applies if the place of taking over of the goods and the place of delivery are situated in different countries, of which at least one is a contracting country (see also: Szanciło, 2013, p. 52). Article $1 \$ 1$ of CIM provides that it should be applied when the place of taking over of the goods and the place designated for delivery are situated in two different member states. Moreover, Article $1 \S 2$ CIM extends its application also to situations when the place of taking over of the goods and the place designated for delivery are situated in two different states, of which at least one is a member state and the parties agree that the contract is subject to the convention. Noticeably, both of the conventions may be applied two-fold. Firstly, the convention may be applicable due to the fulfilment of the conditions set out in Article 1 (1) CMR or Article $1 \$ 1$ CIM. Secondly, the legal relationship may be governed by the particular convention because the parties have agreed so. The second aspect can be seen clearly in the light of the Article $1 \S 2$ CIM, but also CMR convention may be applied as lex contractus. Admittedly, not all legal systems allow such a solution and, for example, under Polish law it

\footnotetext{
3 Convention for the Unification of Certain Rules for International Carriage by Air signed in Montreal on 28 May 1999. Consolidated text: Journal of Acts 2007, No 37, item 235.

4 Convention for the Unification of Certain Rules Relating to International Carriage by Air signed in Warsaw on 12 October 1929.

5 Protocol to Amend the Convention for the Unification of Certain Rules Relating to International Carriage by Air, signed in Warsaw on 12 October 1929, done in Hague on 28 September 1955.
} 
would not be possible to apply the CMR Convention to domestic transport due to the mandatory nature of the provisions of the Transport law $\operatorname{act}^{6}$ (Dąbrowski in: Ambrożuk et al., 2015, p. 54; Wesołowski, 2013, p. 279), but the admissibility of such solution is advocated i.a. by the French courts (decision of Cour de Cassation of 1 July 1997, RD 1998, s. 144) and Dutch courts (decision of Arrondissementsrechtbank Rotterdam of 1 August 1996 r., S\&S 1997, p. 22).

Consequently, the paramount clause also performs two functions. On the one hand, it is merely informative in situations where a particular transport is ex lege governed by one of the conventions. On the other hand, the clause also aims to promote the application of CMR and CIM by contractually including it to the legal relationship in cases where those acts would not, in principle, apply (Górski, Wesołowski, 2006, p. 264; Loewe, 1975, p. 22). Therefore, the qualification of the paramount clause as a declaration of intent or as a declaration of knowledge will depend on the merits of any specific case. For example, if the road transport operation is carried out in conditions which result in the application of the CMR convention on the basis of its provisions, it will apply regardless of the existence of the clause, or even of the drawing up of the consignment note at all. A declaration by the parties in this respect will have no legal effect and will only constitute a declaration of knowledge confirming the already existing legal situation. If, however, the contract covers a carriage to which the CMR convention will not be applied ex lege, the inclusion of a paramount clause in the consignment note should be considered as a declaration of intent. In this situation the basis for the application of the convention will not be derived from the provisions of the act, but from the agreement of the parties.

It should be also mentioned that in Italian case-law the inclusion of a paramount clause in a consignment note is regarded as a sine qua non condition for the application of CMR convention. In the decision of the Italian Supreme Court of 28 November 1975 it was stated that, in the absence of this clause, the carriage is not subject to the CMR at all (see: Cass. I, 2 November 1975, Revue de Droit Uniforme, 1976.247, 26 November 1980, Revue de Droit Uniforme 1981.271, as cited by Mercadal: in: Theunis, 1987, p. 36). Similar, but diverging views were expressed by Italian courts later (see, for example: decision of Corte di Cassazione of 19 June 1981, Foro Padano 1981, p. 106, decision of Corte d'Apello di Milano of 26 May 1981, Foro Padano 1981, pp. 242-251). In the latter judgment the court stated that the obligation to include a paramount clause would be meaningless if the convention applied regardless of whether the parties so agreed. Consequently, the court assumed that if a consignment note existed, CMR would apply only if it contained a paramount clause. The courts have also expressed the more general view that CMR is binding on the parties only if they agree so (decision of Tribunale di Trieste judgment of 17 September 1996, Il diritto marittimo 1998, 1189-1196; decision of Corte di Cassazione of 23 February 1998, Il Diritto marittimo, 2000, I, 132-135, Il Foro Italiano, 1999, I, col. 258-260). It should be mentioned however, that this position was heavily criticized, since it would result in admissibility of voluntary derogation from the convention, which would be contrary to Article 41 CMR. Moreover, according to Article 4 CMR even the complete absence of a consignment note does not exclude its application. The more so it should not be ruled out by any shortcomings in its content (Hill et al., 2000, p. 72; Mercadal in: Theunis, 1987, p. 36). From the perspective of the issue at hand it is important to note that acceptance of the standpoint of the Italian courts

6 Ustawa z 15.11.1984 r. Prawo przewozowe. Dz.U. 1984, nr 53, poz. 272. 
would also mean that the paramount clause will always constitute a declaration of intent, since without it the convention would not be applicable. However, the prevailing view of the doctrine would lead to the conclusion that since the scope of both conventions is essentially determined by Article 1 (1) CMR and Article $1 \$ 1$ CIM, irrespective of the existence and the content of the consignment note or the will of the parties, the inclusion of a paramount clause is only a statement of knowledge, if the conditions set out in these provisions are met.

\section{CARRIER'S LIABILITY FOR PARAMOUNT CLAUSE}

Responsibility for the lack of paramount clause could take several forms. They will be analysed on the background of the exemplary case where the goods are damaged during the performance of a contract of carriage. As a result of this event, the entitled person may claim damages from the carrier. In the course of legal proceedings, a dispute may arise as to whether the convention is applicable at all. In such circumstances a number of different situations need to be distinguished. The first one is the case where the convention applies, but the failure of the carrier to include the clause creates a dispute in this respect and the person entitled to claim damages incurs additional costs (Loewe, 1975, p. 28). In this case the paramount clause constitutes only a declaration of knowledge and the carrier would undoubtedly be liable for the damage caused, because if that clause had been included in accordance with the requirements of the convention, the dispute would not have arisen at all. Noticeably, this type of liability would be independent of the liability for damage to the goods within the meaning of Article 17 CMR or Article 23 CIM.

Secondly, it may also be the case that the convention would not apply at all in the absence of a corresponding clause, because the states where the goods are taken over and where they should be delivered are not the parties to the CMR or the CIM convention. In that situation, the convention could apply only as lex contractus, as a result of the declaration of intent of the parties who would be thereby creating the content of the legal relationship (Hill et al., 2000, 36; Clarke, 2009, p. 17; Dąbrowski in: Ambrożuk et al., 2015, p. 122). As has been mentioned, this will not always be possible, but even if it were, it does not seem justified to make the carrier liable for the consequences of the application of the domestic law of the particular state in a case, where the convention itself does not provide for its application. It would then be difficult to find the carrier's obligation to include a clause to this effect, let alone his liability for breaching it. In addition, it is also important to bear in mind the aim of the paramount clause, which is, after all, to promote the application of the convention, but not to make it a compulsory legal regime for all contracts of carriage. Consequently, the carrier could only be held liable for damage to the goods in accordance with the provisions of law that would apply in the particular case.

There is also a third possibility. Under both acts, a situation may arise in which the contract of carriage falls within the scope of Article 1(1) CMR or Article 1(1) CIM, but the dispute is brought before the court in a state not being the party to the convention in which the defendant is ordinarily resident (Article 31(1)(a) CMR and Article 46(1)(a) CIM) or in which the place where the goods were taken over or the place designated for delivery is situated (Article 31(1) (b) CMR and Article 46(1)(b) CIM). The application of the convention in this case will not be the result of the declaration of intent of the parties, but of the unambiguous wording of the provi- 
sions referred to, which are further strengthened by the clauses contained in Article 41 of CMR and Article 5 of CIM. However, it cannot be ruled out that, in the circumstances of a particular case, a court of state which is not a party to the convention will refuse to apply the convention and will refer only to its domestic law as a result of the application of the rules regarding the conflict of law. This could also be the case even for states being the parties to the convention, e.g. on the basis of the standpoint presented by the Italian courts.

In these circumstances the carrier could be held liable for not having invoked the paramount clause. Including it in a consignment note would have the effect that, irrespective of the application of the convention ex lege, the parties would additionally confirm its application by including a declaration of knowledge in a bilaterally signed document. However, the practical importance of including this clause would be derived from the fact that it would definitely lead to the application of the CMR or CIM convention by the court. This is particularly true for the cases tried before the Italian courts, but it may be also similar in other situations. Even if the court of a state not being the party to the convention did not apply the convention because of the absence of a reference to the convention in the regulations regarding conflicts of law, it would probably apply it because the parties had agreed so. This would not always be the case, since it cannot be ruled out that, despite the paramount clause, the court would refuse to apply the convention on the grounds, for example, of a public policy clause (Wesołowski, 2013, p. 101). However, the rule would continue to be that the convention regime should be applied on the basis of the convention itself, although from the litigation perspective the essential importance would be assigned to the appropriate entry in the consignment note.

In such situation, regardless of the proceedings for compensation for damage to the goods, consideration should be given to the possibility of bringing a separate action for compensation for damage suffered as a result of the fact that the CMR or CIM convention did not apply. In such circumstances, the problem of proving the scope of the damage emerges. The injured party would have to prove that, as a result of non-inclusion of the paramount clause, the convention did not apply, but it would have been otherwise if it had been included. Even if this condition can be met, it will be much more difficult to prove that the party has consequently not been awarded compensation or has been awarded less than it would have been entitled to if the convention had been applied (Loewe, 1975, p. 28). A comparative assessment of the two amounts, depending on whether the CMR/CIM convention or the national law of the state concerned applies, would therefore require significant evidential activity of the claimant. Nonetheless, depending on the rules of law governing onus of proof regarding the damage, there is still a risk that the court would consider that the claimant did not prove the damage with sufficient likelihood.

For example, under Polish law, out of the three classic prerequisites of contractual liability (Czachórski, Brzozowski, Safjan, Skowrońska-Bocian, 1994, p. 230; Zagrobelny in: Gniewek, 2008, p. 846), proving non-performance of the obligation should not be difficult. It will also be relatively easy to establish a causal link. The most difficult thing to prove would be the fact that the damage has actually occurred. In this respect the nature of this damage should be established. On the one hand, it could be considered to be a loss (damnum emergens), defined as a deterioration in the economic situation of an injured party as a result of an event to which liability relates (Radwański, Olejniczak, 2010, p. 92). This may include a decrease in assets or a decrease in liabilities (Zagrobelny in: Gniewek, 2008, p. 568). From the perspective of the time criterion, em- 
phasis is placed on an undesirable change in legal situation of the aggrieved party existing before the infringement (Kaliński in: Olejniczak, 2018, p. 107). In the case at hand, however, it should be remembered that two damaging events have occurred: the first is the damage to the goods and the second is the non-inclusion of a paramount clause. The former is undoubtedly fully in line with the classic concept of loss. However, the latter event is of key importance and when analysing it, the damage to the goods should be omitted. From this perspective it is necessary to consider the concept of lost profit (lucrum cessans), which is a type of indirect damage (Kaliński in: Olejniczak, 2018, p. 107) and covers a situation in which the party's assets did not increase as if it had occurred in the absence of the causal event (Radwański, Olejniczak, 2010, p. 92). In this case it should be determined what the situation of the damaged party would be like in the absence of an event giving rise to the damage (Zagrobelny in: Gniewek, 2008, p. 569). Bearing in mind the fact that the damage derives from the non-inclusion of the relevant clause in the consignment note, the view must be taken that the damage in question constitutes a specific form of lost profit. Although the concept of 'profit' may seem to be not entirely adequate, this is the situation which is in fact described in the case at hand. After all, it is a matter of determining the value of the benefit which the injured party would have received had the event not occurred. This benefit is precisely the difference between the compensation actually granted under national law and that which would have been received had one of the transport conventions been applicable.

Nevertheless, the classification of the damage as a lost profit does not improve the situation of the person claiming damages from the carrier. If the case were brought before a Polish court, this person has to consider the perpetuated view of the jurisprudence that the likelihood of obtaining the profit must be demonstrated with the probability close to certainty (see i.a. decisions of Polish Supreme Court of: 22 April 2015., III CSK 256/14, Legalis 1310206; 22 January 2008 r., II CSK 377/07, Legalis 491899; 26.01.2005 r., V CK 426/04, Legalis 1322547; 28 April 2004 r., III CK 495/02, Legalis 67957; 28 January 1999 r., III CKN 133/98, Legalis 346141). Therefore, it would be extremely difficult to prove that if the paramount clause was included, the court would apply the convention instead of national law and award damages of a certain amount. Furthermore, there is a risk that such damage would be considered as a so-called potential damage. In the doctrine, the latter concept is often compared with the damage constituting lucrum cessans. However, it is underlined that the factor diverging these two concepts is the likelihood of the realization of the opportunity. Potential damage can only be considered as such if the probability of the injured party's expected course of events was less than highly probable (Kaliński in: Olejniczak, 2018, p. 108). It therefore represents the benefits that the injured party could have potentially obtained, but the likelihood of obtaining them was not high enough (Zagrobelny in: Gniewek, 2008, p. 569) The case at hand is somewhat similar and there would be a risk that the court would accept the chances of obtaining the compensation under the convention being too low and decide that it is not possible to establish with a sufficient degree of probability the amount of damages that would be awarded. Consequently, this would have led to the dismissal of the case on the ground that it had not been proved that the damage had occurred. 


\section{CONCLUSION}

Bearing in mind the abovementioned remarks it should be noted that the situation of the party suing the carrier for the damage sustained as a result of the lack of paramount clause would be diversified. In the first case, when the damage would consist of the additional costs borne due to the need of determining the applicable act, the position of the claimant would be relatively good. In the second situation, where the convention would be applicable only as lex contractus, the claimant would have not been entitled to any damages at all, since it would refer only to the cases, when the application of the convention is voluntary and therefore there is no obligation of the carrier. The most important is the last of the three described situations, where the lack of the paramount clause would result in the non-applicability of the convention by the court, which would have applied it had the clause been included. This issue should be perceived with the consideration of the provisions of applicable national law, in particular regarding the concept of damages and the evidentiary aspects. When it comes to Polish law, the main difficulty would be related to proving the actual damage. It may be assumed that in many other countries this issue may also be the problem. Passing a favourable decision for the claimant would require the assessment of the damages actually awarded and the potential damages. In this situation not only it would be necessary to refer to the foreign law by the court trying the case, but it would also need to pass the decision only on the basis of assumptions of the possible decisions of the foreign courts. Based on the calculus of probability the court may come the conclusion that it is to low and will be probably reluctant to award damages from the carriers. Moreover, the effective redress would be further hampered by the short statute of limitations applicable to the contract of carriage.

\section{REFERENCES}

Ambrożuk, D., Dąbrowski, D., Wesołowski, K. (2015). Konwencja o umowie międzynarodowego przewozu drogowego towarów (CMR): komentarz. Warszawa: Wolters Kluwer.

Clarke, M.A. (2009). International carriage of goods by road: CMR. London: Informa.

Clarke, M.A., Yates, D. (2008). Contracts of carriage by land and air. London: Informa.

Czachórski, W., Brzozowski, A., Safjan, M., Skowrońska-Bocian, E. (1994). Zobowiązania: zarys wykładu. Warszawa: Wyd. Naukowe PWN.

Gniewek, E., Burian, B. (eds.) (2008). Kodeks cywilny: komentarz. Warszawa: C.H. Beck.

Godlewski, J. (2007). Przepisy ujednolicone o umowie międzynarodowego przewozu towarów kolejami (CIM). Gdynia: Wyd. Polskiej Izby Spedycji i Logistyki.

Górski, W., Wesołowski, K. (2006). Komentarz do przepisów o umowie przewozu i spedycji: Kodeks cywilny - Prawo przewozowe - CMR: stan prawny na dzień 15 sierpnia 2005 r. Gdańsk: ODDK.

Hill, D.J., Messent, A.D., Glass, D.A. (2000). CMR: contracts for the international carriage of goods by road. London: Lloyd's of London Press.

Loewe, R. (1975). Commentary on the Convention of 19 May 1956 on the Contract for the International Carriage of Goods by Road (CMR). Geneve.

Olejniczak, A. (ed.) (2018). System prawa prywatnego. Tom 6. Prawo zobowiązań - część ogólna. Warszawa: C.H. Beck.

Radwański, Z., Olejniczak, A. (2010). Zobowiązania - cześć ogólna. Warszawa: C.H. Beck.

Szanciło, T. (2013). Odpowiedzialność kontraktowa przewoźnika przy przewozie drogowym przesyłek towarowych. Warszawa: C.H. Beck.

Theunis, J. (ed.) (1987). International carriage of goods by road (CMR). London, New York: Lloyd's of London Press.

Wesołowski, K. (2013). Umowa międzynarodowego przewozu drogowego towarów na podstawie CMR. Warszawa: Wolters Kluwer. 
Klauzula paramount w drogowym i kolejowym międzynarodowym transporcie towarów

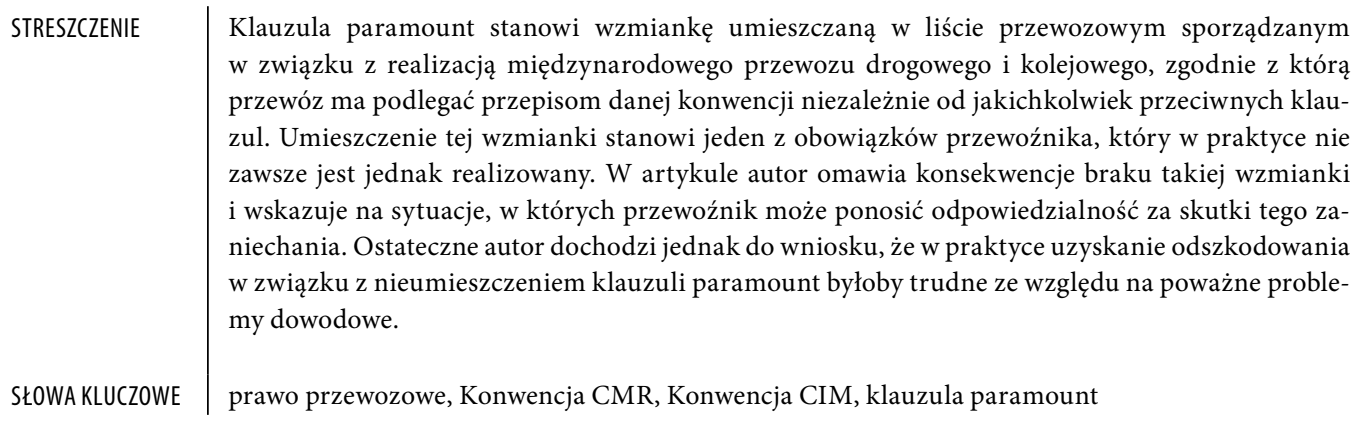

Translated by Konrad Garnowski 